\title{
SPATIAL PATTERN OF EDUCATIONAL DEVELOPMENT AT BLOCK LEVEL IN JALORE DISTRICT, RAJASTHAN
}

\author{
Shivani Swarnkar ${ }^{1}$ and Siddhartha Kumar Gaurav ${ }^{2}$ \\ ${ }^{1}$ Assistant Professor, Department of Geography, \\ Govt. Meera Girls College, Udaipur, (Rajasthan) India \\ ${ }^{2}$ Research Scholar, Department of Geography, \\ Mohanlal Sukhadia University, Udaipur, (Rajasthan) India \\ Email: siddharthakgaurav@gmail.com
}

\begin{abstract}
Human development of any region depends upon educational development, but such a development can't take place without simultaneous development of educational amenities in all areas of a region/country. An amenity is a set of facilities of providing goods and services to the public through which quality of life of peoples of a region is improved. Regional disparity is worldwide problem today, especially in the developing countries. The present study is an attempt to examine the spatial pattern of educational amenities development in Jalore district. The Study reveals that Jalore district has regional disparities in educational amenities development. The study concluded that the pattern of educational development is not uniform in all the areas of district due to lack of harmonious development of educational amenities in all the blocks of the district.
\end{abstract}

Key word: Amenity, Education, Disparity, Social Development, Spatial Pattern

\section{Introduction}

There has been a growing school of thought that human development is not just economic growth but it is also about growth with expansion of Choice, access to services and participation of people in the process of development leading to their empowerment and improvement of wellbeing. It has been realized that expectancy of life, education, health and access to resources are the most crucial choice to live a decent life. Development is the improvement in the wellbeing of the people through social, economic, political and amenities transformation. Among various dimension of development, present study deals with spatial pattern of educational amenities development in Jalore district. The term amenities refer to the infrastructure that supports a society such as roads, railway, schools, hospitals, bank, communication, electricity, and telephone facilities etc. An amenity is a set of facilities through which goods and services are provided to the public of any region, which shows the quality of life of peoples in a region.

The education amenities development is cardinal base of human development in any society or region and it is the most important factor of development. The socio-economic conditions in any society and any country depend upon the availability of educational facilities. But, even after seven decades of independence, there are many such areas in the country where there is lack of education facilities, especially in the rural, tribal, desert and mountainous regions. There are large numbers of studies have been published on the issues of educational amenities development at the national and state level. But there is no particular study on the spatial pattern of educational amenities development in Jalore district of Rajasthan. Therefore, attempt is made to analyze the different level of educational amenities development in the district. Jalore district is the most backward district in terms of literacy rate in the Rajasthan state having lowest literacy rate (Census of India 2011). Therefore, this analysis has been undertaken to assess the development level of educational facilities in this district for balanced development of different areas.

\section{Study Area}

Jalore district is situated at the south-western corner of Rajasthan state adjoining the Gujarat state between $24^{\circ} 37^{\prime}$ to $25^{\circ} 49^{\prime}$ North latitude and $71^{\circ} 11^{\prime}$ to $73^{\circ} 05^{\prime}$ East longitude. The district 
covers an area of 10,640 square kilometers with eight blocks and a population of 1828,730 (936,634 males and 892,096 females). There are eight blocks in district are Ahore, Bhinmal, Chitalwana, Jalore, Jaswantpura, Raniwara, Sanchore, and Sayla.

Figure 01: Location of Study Area

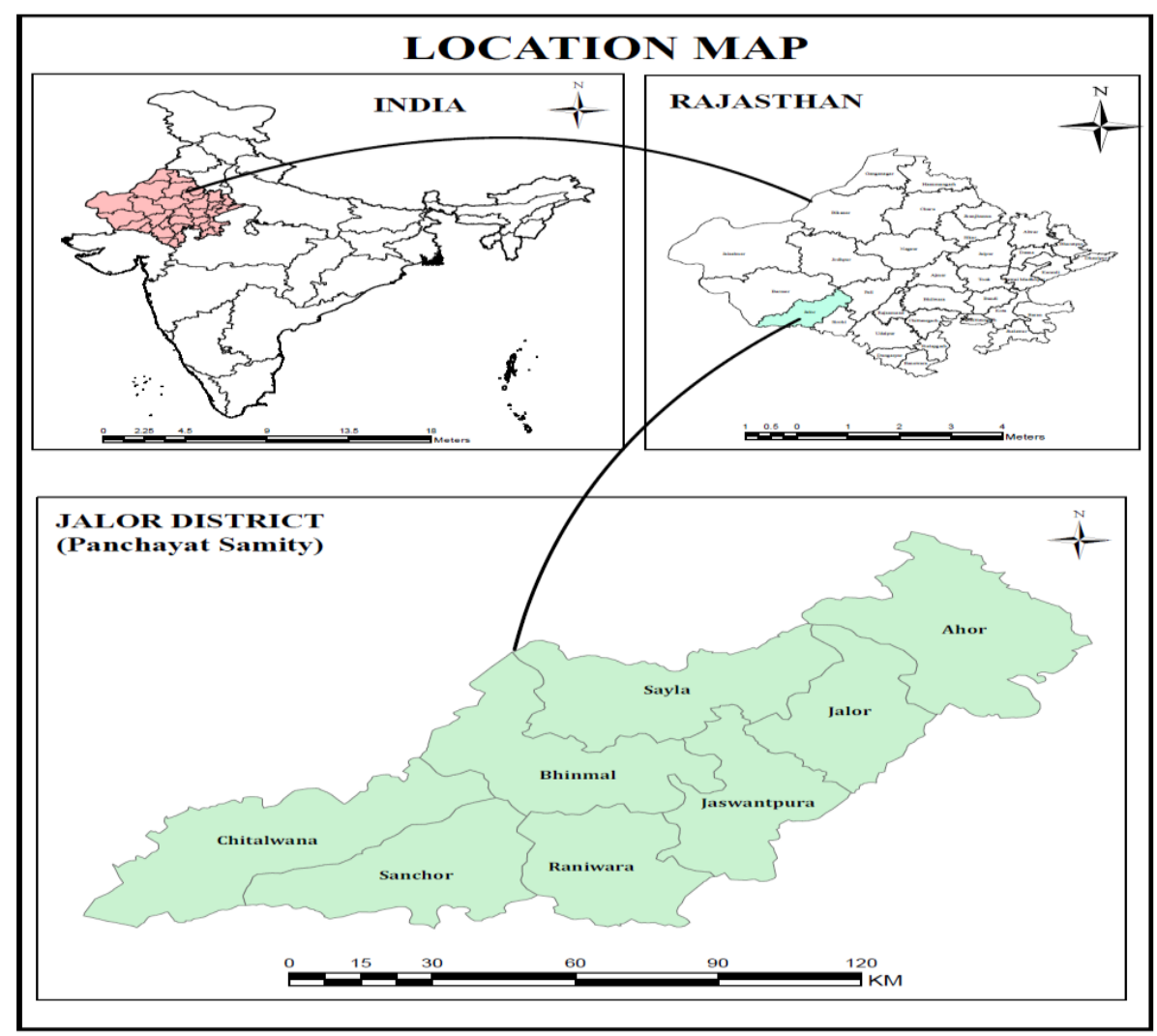

\section{Objectives of the Study}

The objectives of the study are:

- Examine the spatial pattern of educational development in the district.

- Analyze the level of inter-blocks disparities in the educational amenities development in the district.

\section{Database and Methodology}

The study is based on secondary data collected from office of the Chief District Education of Jalore district and U-DISE portal of the district for the educational Session 2018-19. The ZSquare Method has been used to analyze the spatial distribution of educational amenities development. In view the current state of the education facilities of the district 16 indicators have been selected to measure the educational development level and these are:

- $\mathrm{X} 1$ : Number of primary schools per 5000 persons.

- X2: Number of upper primary schools per 10000 persons.

- X3: Number of secondary schools per 15000 persons.

- X4: Number of senior secondary schools per 20000 persons.

- X5: Number of primary schools per 500 square kilometers.

- X6: Number of upper primary schools per 1000 square kilometers.

- X7: Number of secondary schools per 1500 square kilometers.

- X8: Number of senior secondary schools per 2000 square kilometers.

- $X_{9}$ : School/Teacher Ratio in primary schools.

- $X_{10}$ : School/Teacher Ratio in upper primary schools.

- $\mathrm{X}_{11}$ : School/Teacher Ratio in secondary schools.

- $\mathrm{X}_{12}$ : School/Teacher Ratio in senior secondary schools.

- $\mathrm{X}_{13}$ : School/Student Ratio in primary schools.

- $\mathrm{X}_{14}$ : School/Student Ratio in upper primary schools.

- $X_{15}$ : School/Student Ratio in secondary schools.

- $\mathrm{X}_{16}$ : School/Student Ratio in senior secondary schools. 
The composite value of all selected indicators represents overall scenario of inter-block and intra-block disparity in level of educational development. The level of amenities development has been divided into three categories like high, moderate and less developed based on composite value. The following different formulas have been applied to calculate composite index.

1. Firstly, standard values have been calculated by following formula

Standardized value $=\frac{x-\bar{x}}{\sigma}$

$\overline{\mathrm{x}}=$ Mean of the indictor

$\sigma=$ Standard Deviation of the indicator

2. Gross values of each block have been calculated by grand total of the standardised values of all indicators found in that block.

3. At the end composite index has been calculated.

$$
\text { Composite index }=\frac{\text { Gross Value }}{\mathrm{n}}
$$

\section{Spatial Pattern of Educational Development}

As a result of composite index regional disparities found in the spatial pattern of educational development of various block of the district are shown. On the basis of composite index value blocks are divided into various category of level of educational development. The higher values of composite index relating to the blocks score shows high level of educational development and lower value of the index show low level of educational development. On this basis Jalore district has been divided in three category of level of educational development, which is given in table.3. The study found that the High development of educational amenities is in Jalore block and lowest is in Sayla block. The blocks of Jalore, Sanchore and Ahore have comparatively high educational amenities development than Jaswantpura, Chitalwana and Sayla block.

High Level of Development: This category includes two blocks viz. Jalore and Sanchore. It indicates that the blocks have higher level of educational facilities development in comparison of other blocks. The distribution of educational institutions is similar according to population and as well as area in these blocks. There is large number of students in educational institutes in these blocks.

Moderate Level of Development: The moderately developed category includes four blocks i.e. Ahore, Raniwara, Jaswantpura and Bhinmal. In these blocks educational facilities are equally distributed and are considerably available, according to area and population in comparison to low developed blocks.

Less Level of Development: The two blocks come under this category namely Chitalwana and Sayla which are fully rural. The block Sayla (0.85) shows, least educational development in the district. In these blocks educational facilities are very poor and not equally distributed. There is lack of educational institute according to population and area.

Figure 02: Spatial Pattern of Educational Development

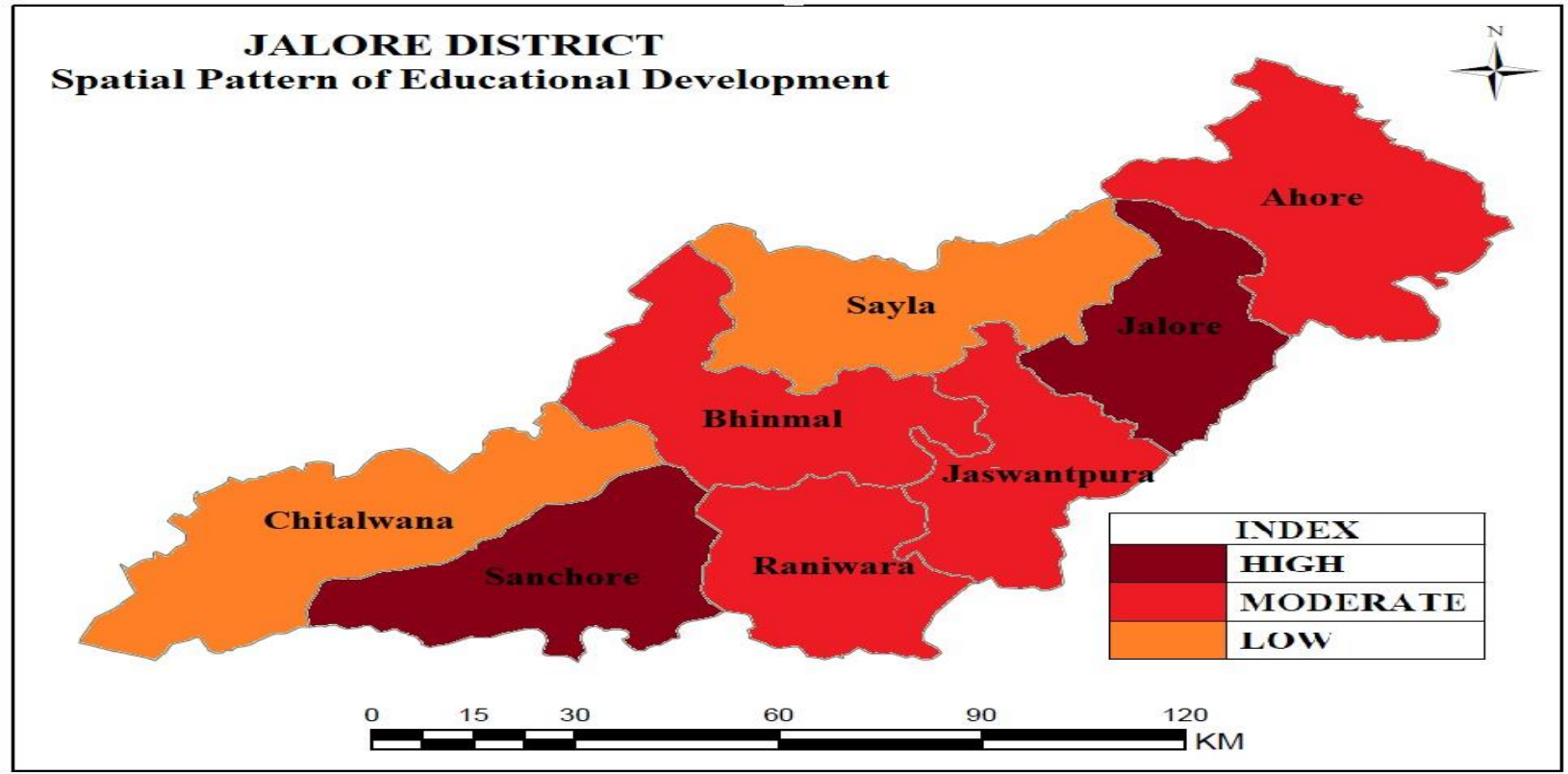


Table 01: Indicators Value of Educational Development

\begin{tabular}{|c|c|c|c|c|c|c|c|c|c|c|c|c|c|c|c|c|c|}
\hline$\#$ & Block & $X_{1}$ & $X_{2}$ & $X_{3}$ & $X_{4}$ & $X_{5}$ & $X_{6}$ & $X_{7}$ & $\mathrm{X}_{8}$ & $X_{9}$ & $X_{10}$ & $X_{11}$ & $X_{12}$ & $X_{13}$ & $X_{14}$ & $X_{15}$ & $X_{16}$ \\
\hline 1 & Ahore & 2.0 & 7.7 & 2.5 & 5.2 & 24.7 & 94.3 & 31.2 & 63.7 & 2.6 & 5.8 & 10.8 & 12.8 & 313.4 & 128.2 & 199.3 & 175.2 \\
\hline 2 & Bhinmal & 3.6 & 7.3 & 1.6 & 3.7 & 66.6 & 137.0 & 29.4 & 69.2 & 2.1 & 5.5 & 10.1 & 11.0 & 55.5 & 160.7 & 244.1 & 237.7 \\
\hline 3 & Chitalwana & 4.8 & 4.9 & 1.9 & 3.9 & 56.4 & 57.0 & 21.6 & 45.4 & 1.5 & 5.3 & 10.8 & 12.2 & 44.6 & 172.0 & 226.6 & 240.3 \\
\hline 4 & Jalore & 1.7 & 9.1 & 3.0 & 6.0 & 27.3 & 144.5 & 47.0 & 95.0 & 2.7 & 6.3 & 11.1 & 14.2 & 58.0 & 134.3 & 193.2 & 177.6 \\
\hline 5 & Jaswantpura & 2.6 & 5.9 & 1.3 & 4.1 & 38.5 & 86.3 & 19.7 & 60.0 & 2.0 & 6.0 & 11.9 & 11.1 & 113.7 & 178.4 & 263.7 & 220.6 \\
\hline 6 & Raniwara & 4.7 & 5.4 & 1.3 & 4.4 & 98.8 & 113.5 & 27.4 & 93.2 & 1.6 & 5.1 & 10.4 & 12.8 & 40.8 & 148.6 & 225.1 & 256.2 \\
\hline 7 & Sanchore & 3.9 & 5.8 & 1.9 & 4.5 & 79.5 & 119.2 & 39.3 & 93.0 & 1.8 & 5.3 & 10.5 & 14.1 & 48.8 & 159.1 & 236.2 & 286.9 \\
\hline 8 & Sayla & 3.3 & 5.6 & 0.9 & 3.3 & 60.1 & 100.9 & 15.4 & 60.4 & 1.6 & 5.8 & 10.4 & 11.6 & 51.7 & 181.4 & 206.1 & 239.6 \\
\hline 9 & Mean & 3.3 & 6.5 & 1.8 & 4.4 & 56.5 & 106.6 & 28.9 & 72.5 & 2.0 & 5.6 & 10.8 & 12.5 & 90.8 & 157.8 & 224.3 & 229.3 \\
\hline 10 & SD & 1.2 & 1.4 & 0.7 & 0.9 & 25.7 & 28.3 & 10.4 & 18.8 & 0.5 & 0.4 & 0.6 & 1.2 & 92.8 & 19.7 & 24.0 & 37.8 \\
\hline
\end{tabular}

Source: Chief District Education Office, Jalore, 2018-19

Table 02: Spatial Pattern of Educational Development

\begin{tabular}{|c|c|c|c|c|c|c|c|c|c|c|c|c|c|c|c|c|c|c|c|c|}
\hline$\#$ & Block & $X_{1}$ & $X_{2}$ & $X_{3}$ & $X_{4}$ & $X_{5}$ & $X_{6}$ & $X_{7}$ & $X_{8}$ & $X_{9}$ & $X_{10}$ & $X_{11}$ & $X_{12}$ & $X_{13}$ & $X_{14}$ & $X_{15}$ & $X_{16}$ & $\begin{array}{l}\text { Gross } \\
\text { Value }\end{array}$ & $\begin{array}{c}\text { Composite } \\
\text { Value }\end{array}$ & Rank \\
\hline 1 & Ahore & -1.1 & 0.9 & 1.0 & 0.9 & -1.2 & -0.4 & 0.2 & -0.5 & 1.3 & 0.4 & 0.1 & 0.3 & 2.4 & -1.5 & -1.0 & -1.4 & 0.273 & 0.017 & 3 \\
\hline 2 & Bhinmal & 0.2 & 0.6 & -0.3 & -0.8 & 0.4 & 1.1 & 0.1 & -0.2 & 0.2 & -0.3 & -1.2 & -1.2 & -0.4 & 0.1 & 0.8 & 0.2 & -0.552 & -0.034 & 6 \\
\hline 3 & Chitalwana & 1.3 & -1.1 & 0.1 & -0.6 & 0.0 & -1.7 & -0.7 & -1.4 & -1.1 & -0.8 & 0.1 & -0.2 & -0.5 & 0.7 & 0.1 & 0.3 & -5.543 & -0.346 & 7 \\
\hline 4 & Jalore & -1.4 & 1.8 & 1.7 & 1.9 & -1.1 & 1.3 & 1.7 & 1.2 & 1.6 & 1.6 & 0.6 & 1.4 & -0.4 & -1.2 & -1.3 & -1.4 & 8.178 & 0.511 & 1 \\
\hline 5 & Jaswantpura & -0.6 & -0.4 & -0.7 & -0.3 & -0.7 & -0.7 & -0.9 & -0.7 & 0.0 & 0.9 & 2.1 & -1.1 & 0.2 & 1.0 & 1.6 & -0.2 & -0.460 & -0.029 & 5 \\
\hline 6 & Raniwara & 1.2 & -0.7 & -0.7 & 0.0 & 1.6 & 0.2 & -0.1 & 1.1 & -0.8 & -1.3 & -0.6 & 0.3 & -0.5 & -0.5 & 0.0 & 0.7 & -0.216 & -0.013 & 4 \\
\hline 7 & Sanchore & 0.5 & -0.5 & 0.1 & 0.1 & 0.9 & 0.4 & 1.0 & 1.1 & -0.4 & -0.8 & -0.4 & 1.3 & -0.5 & 0.1 & 0.5 & 1.5 & 4.994 & 0.312 & 2 \\
\hline 8 & Sayla & 0.0 & -0.6 & -1.3 & -1.3 & 0.1 & -0.2 & -1.3 & -0.6 & -0.8 & 0.4 & -0.6 & -0.7 & -0.4 & 1.2 & -0.8 & 0.3 & -6.674 & -0.417 & 8 \\
\hline
\end{tabular}

Source: Calculated By Authors 
Table 3: The level of educational Development

\begin{tabular}{|c|l|c|l|l|}
\hline \multirow{2}{*}{$\#}$. & \multicolumn{1}{|c|}{ Category } & Composite & \multicolumn{2}{|c|}{ Block } \\
\cline { 4 - 5 } & & Index Value & Number & Name \\
\hline 1. & High Development & Above 0.3 & 2 & Jalore, Sanchore \\
\hline 2. & $\begin{array}{l}\text { Moderate } \\
\text { Development }\end{array}$ & -0.35 to 0.3 & 4 & $\begin{array}{l}\text { Ahore, Raniwara, Jaswantpura, } \\
\text { and Bhinmal }\end{array}$ \\
\hline 3. & Less Development & Below -0.35 & 2 & Sayla, Chitalwana \\
\hline
\end{tabular}

Source: Calculated by authors

\section{Recommendations}

1. Government should be provided better educational facilities to students in those schools which are located in backward area.

2. Number of educational institution, enrolment of students and number of teachers should be increased according to area and population in Chitalwana and Sayla block.

3. There is no technical educational institute in district, required to be established in all block headquarters of district.

4. Senior secondary school should be set up in villages having population of more than four thousand.

5. Distribution of educational institutions should be uniform according to population and area in district.

6. Availability of upper primary schools in all villages of district should be increased.

\section{Conclusion}

From the proceeding discussions it may be concluded that the pattern of educational amenities development is not uniform and equally distributed in all the blocks of Jalore district. Most of rural areas and population are facing lack of educational facilities development in the district. It is also found that the Jalore and Sanchore block have comparatively high educational development than Chitalwana and Sayla block. It may be concluded that there is a very high regional disparity and backwardness in the level of educational facilities in rural areas of Jalore district, so government should not only focus on amenities development but also focus on equivalent development of all blocks of the district. Therefore the blocks with low level of development should be given top priority so that they may come to the level of developed areas and the concept of planning with social justice sustainable development may be fulfilled.

\section{References}

1. Ansari, S.A. and Rajender. (1995) Strategy for the Development of Educational Facilities in Rohtak District, Hariyana. Annals of Rajasthan Geographical Association, Vol. 13, pp. 25-28

2. Kothari, Sadhna. (2003) Analysis of Spatial Disparities in Education and Health Facilities in India. Annals of Rajasthan Geographical Association, Vol. 17-18, pp. 51-57.

3. Makkar, Aparna. (1999) Education and Socio-Economic Development in India: Some Generalisation of a Historical Analysis. Rajasthan Economic Journal, Vol. 23 (2), pp 39-55.

4. Naseer Y., Siddiqui F.A. and Khan, K. (2005) Dimensions of Education Development and Its Correlates in Western Uttar Pradesh. Indian Journals of Regional Science, Vol.37 (1), pp. 101-110.

5. Swarnkar Shivani and Chaudhary Kirti. (2018) Spatial Variation in Educational Amenities of Talwara Block of Banswara District. Journal of Global Resources Vol. 4 (2) pp. 47-53

6. Swarnkar Shivani and Rawal, Khetpal (2018) Spatial Variation of Educational Amenities of TSP Area of Rajasthan. Annals of Rajasthan Geographical Association Vol. 34 pp. 44-51. 